\title{
Research Notes
}

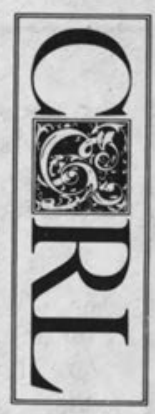

\section{Bibliographic Instructors in the Sciences: A Profile}

\author{
Joy Thomas
}

Responses of 100 librarians to a questionnaire revealed a profile of the educational background and attitudes of science librarians involved in bibliographic instruction. A follow-up survey explored the degree to which library school curricula prepare librarians for bibliographic instruction.

Several years ago the University Library of California State University, Long Beach (CSULB), experienced an apparent shortage of science-educated librarians simultaneous with a need to introduce hundreds of science majors each semester to library research. New librarians without science backgrounds, of whom I was one, were assigned to what was then the science and technology department. While some had academic library experience, bibliographic lecturing was a new and unnerving duty. Neither education nor experience had prepared these librarians to deal with what was perceived as the exotic, highly technical literature of the sciences. The only orientation for most had been a dimly remembered course in science bibliography in library school. ${ }^{1}$ Later, as CSULB's li- brary instruction coordinator, I undertook a statewide survey of science librarians involved in bibliographic instruction in an effort to determine how training for librarians to give instruction had been accomplished at other libraries. The results did not solve our dilemma, but did reveal an interesting profile of bibliographic instruction librarians. Librarian response to the questionnaire precipitated an additional, albeit brief, survey of library school education in bibliographic instruction techniques. The literature, though rife with articles on familiarizing students with the bibliography of a specific discipline, lacked information on exactly how librarians are trained to render bibliographic instruction, especially in unfamiliar fields.

\section{METHODOLOGY}

\section{Purpose}

Some of the survey goals were similar to those previously reported by Barbara Smith; others were more qualitative. ${ }^{2} \mathrm{My}$ purposes were:

1. To determine whether other institu- 
tions had trained their science librarians in bibliographic instruction techniques in a more systematic way than had CSULB.

2. To determine by what means, in addition to formal training, librarians had developed instructional skills.

3. To determine whether other institutions limited scientific bibliographic instruction to librarians with an appropriate educational background.

4. To determine whether enjoyment of bibliographic instruction in the sciences was influenced by possession of an educational background in the sciences and/or specialized training in bibliographic instruction skills.

5. To determine the degree to which library school curricula have prepared and are currently preparing information professionals to meet the challenge of instructing library users.

\section{The Sample}

A preliminary version of the survey was pretested on all seventeen of my colleagues who participated in bibliographic instruction at the time. Their responses and comments helped clarify some questions. They were not surveyed further, nor were they included in the final results. See figure 1 for survey instrument and raw responses.

Surveys, along with self-addressed stamped envelopes, were mailed to 144 California science librarians believed to be engaged in bibliographic instruction. The basis of this sample was a directory of science librarians compiled by an officer of SEAL (Science \& Engineering Academic Librarians), an interest group of CARL (California Academic \& Research Librarians, an ACRL chapter). ${ }^{3}$ Individuals in this directory were indexed not only by name and institution but also by job responsibilities. Twelve questionnaires were returned with only the first box checked, indicating that the respondent was not involved in bibliographic instruction. Excluding these 12 , a $77.7 \%$ response rate was attained, with exactly 100 completed questionnaires returned.

\section{Results}

Academic librarians (two- and four-year schools) accounted for 98 of the respondents. Of these, 57 had been librarians for ten years or more; and 43 had a bachelor's, master's and/or a doctorate in a scientific or technical discipline. Given CSULB's earlier difficulty in recruiting science librarians, this high percentage was surprising. The survey showed that most ( $n$ = 37) of the librarians giving bibliographic instruction in biology, medicine, chemistry, or engineering had a degree in a scientific discipline.

Enjoyment level was high. On a fivepoint scale, the majority of librarians giving bibliographic instruction in each discipline rated their enjoyment 1 or 2 . In the sciences, the percentages varied from all four of the librarians giving instruction in astronomy (100\%) to $65 \%$ of those giving instruction in unspecified scientific fields. Though the numbers are too small to draw conclusions, respondents expressed a high degree of satisfaction even in the nonscientific fields: $100 \%$ of the science librarians giving instruction in applied arts and in fine arts rated their enjoyment 1 or 2. The least enjoyed nonscience field was "Other," with only $62.5 \%$ rating their enjoyment 1 or 2 . Table 1 shows responses and enjoyment level for each discipline questioned.

\section{"Nearly half of the respondents gave library use instruction only in disci- plines in which they themselves had had course work.'}

The instruction given by a majority of respondents $(n=57)$ was limited to scientific fields. The most often taught nonscience bibliographic instruction subjects were in the social sciences, but this involved less than a quarter of those completing the questionnaire. Contrary to CSULB's expectations at the time, nearly half of the respondents gave library use instruction only in disciplines in which they themselves had had course work. Slightly more than half of the respondents gave instruction in an average of four courses in which they had not had formal education. 
Dear Colleague:

I would like to develop a profile of librarians who give bibliographic instruction in science and technology and would appreciate a few minutes of your time to complete this questionnaire. I recognize that reference work is a form of bibliographic instruction, but $m y$ present interest is in more formal instructional efforts. Please return in the enclosed self-addressed, postage-paid envelope. Thank you.

Joy Thomas

Callifornia State University, Long Beach

If bibliographic instruction is not one of your responsibilities, please check here and return the questionnaire. If it is, please continue.

1. How long have you been a librarian? less than 3 years $=3 ; 3-9$ years $=39 ; 10+=57$

2. If you have had another career, please specify: 33 ( 27 in some form of education)

3. Excluding your library degree, what is your educational background? $\frac{36}{16}$ BNBS in scientific or technical field

MavMS in

6 doctorate in ( 3 in sci or tech) 7 certificate in ( 4 in educational field)

4. In what type tibrary are you presently employed?

89 college/university $\underline{9}$ community college 1 special 1 public $\underline{0}$ other

5. Approximately what percentage of time do you spend on bibliographic instruction, including preparation?

48 less that $10 \times \quad 44$ 10-25x $\quad 4$ 25-50x $\quad 0 \quad 51-75 x \quad 1$ over $75 x$

6. In what areas of science and technology do you give bibliographic instruction?

\begin{tabular}{lll}
$\frac{4}{48}$ astronomy & $\frac{25}{10}$ engineering \\
$\frac{26}{10}$ chemistry & $\frac{15}{10}$ geology & $\frac{13}{7}$ microbiology \\
$\underline{\underline{10}}$ computer studies & $\underline{39}$ medicine & $\frac{7}{43}$ physics \\
\hline
\end{tabular}

7. If you give bibliographic instruction in other disciplines, which ones?

6 applíed arts 10 business 9 education $\quad 7$ fine arts

14 humanities 23 social \& behavioral sciences 16 other

8. If you give bibliographic instruction in disciplines in which you yourself have not had coursework, please list the disciplines.

average $=2$

48 answered zero over, please

94 answered 5 or less

11 answered 2

2 answered $10+$

\section{FIGURE 1}

Bibliographic Instruction in Library Schools Questionnaire Sample 
9. How did you learn to give bibliographic instruction? Check all that apply.

8 library school $\quad \frac{70}{}$ on-the-job training (including in-house workshops)

37 national, state, or regional workshop $\underline{53}$ observation $\underline{71}$ trial-and-error

24 other

10. If you have had training or experience as a teacher, did it help you in bibliographic instruction?

43 yes 1 no $\frac{56}{1}$ not applicable

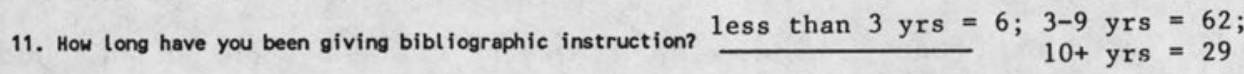

12. Compared to your other duties, what is your attitude about giving bibliographic instruction?

Strong preference

Strong aversion
131
24
${ }^{3} 19$
47
50

13. What is your opinion about the value of bibliographic instruction to students?

Valuable
157
29
$3_{8}$
44

Worthless

14. Please characterize the bibliographic instruction program with which you are involved. Check all that apply.

74 one-time lectures initiated by library

95 one-time lectures requested by professor

30 quarter or semester courses

15 courses shorter than the quarter or the semester

21 other (please specify)

Please use the space below for comments.

22 respondents commented

Thank you for your time. Please return by June 30, 1985, in the enclosed selfaddressed, postage-paid envelope.

\section{FIGURE 1}

Continued 
TABLE 1

BIBLIOGRAPHIC INSTRUCTION BY FIELD-RAW RESPONSES WITH PERCENTAGE INDICATING SATISFACTION LEVELS OF 1 OR 2

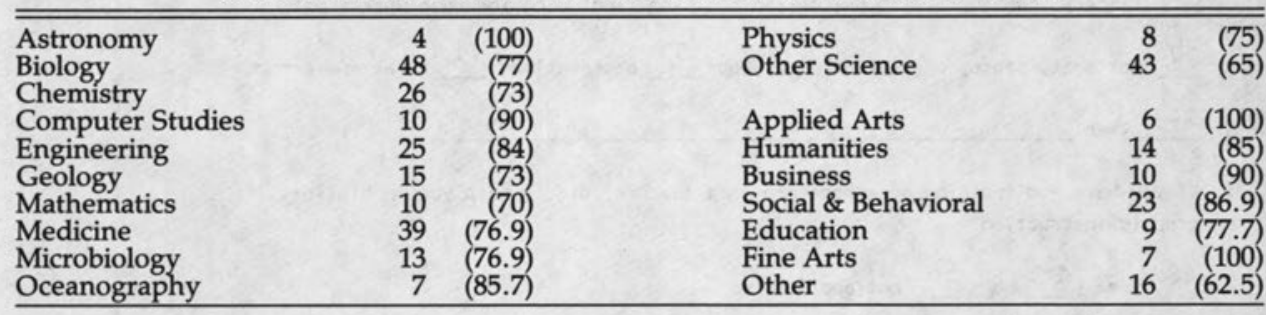

By far the most common methods by which respondents were trained for bibliographic instruction (question 9) were trial and error and on-the-job training (71 and 70 responses, respectively). Stabler's recent study indicated that most newly hired reference librarians believe their onthe-job-training, including training for bibliographic instruction, was inadequate; but $69.9 \%$ of my respondents who got on-the-job-training rated their enjoyment of giving instruction 1 or $2 .^{4}$ Satisfaction level by type of training is shown in table 2. All 57 respondents with ten or more years of experience indicated that they had received more than one method of training. Most frequently cited by these respondents were trial and error $(77.2 \%$; $n=44)$ and on-the-job training (63.1\%; $n$ $=36$ ).

Library school had not instilled instructional skills in these librarians. Of the eight librarians who had some library school course work in bibliographic instruction, half had been in the field less than a decade; but library use instruction was simply not a part of the curriculum when most respondents would have been attending library school, an experience which paralleled mine and that of my colleagues. ${ }^{5}$ However, even those few with some library school exposure supplemented it with other training methods. Of those eight respondents who had had some library school training in bibliographic instruction, six reported that they had been given on-the-job training, and five had observed bibliographic instruction. Three librarians indicated that they had availed themselves of opportunities provided by library school, on-the-job training and observation, but still found themselves engaged in trial and error. My findings paralleled Galloway's; most of her respondents in 1975 had previous teaching experience. ${ }^{6}$ A large minority of respondents $(n=44)$ had training or experience as teachers; all but one found this helpful.

\section{LIBRARY SCHOOLS}

In 1976, Sue Galloway criticized the absence of library instruction courses at library schools; in 1982, Marilyn Lutzker recommended that this ongoing lack be remedied; and in 1983, Howarth and Kenney's syllabi project found that bibliographic instruction was at least a portion of a course in thirty-three library schools. ${ }^{7}$ They did not specify how many schools offered a separate course in bibliographic instruction.

Two years later, there is evidence that a modicum of bibliographic instruction training is offered by library schools. Having discovered from long-term practitioners in the field that their library school training had not included bibliographic instruction, I sent letters to sixty ALAaccredited library schools in the United States and Canada to find out if the situation had changed. Most ( $n=48 ; 80 \%)$ responded. Even though I had not requested them, many included catalogs, course descriptions, and/or syllabi. I asked general, factual questions, less detailed and much less quantifiable than those asked by Maureen Pastine and $\mathrm{Ka}$ ren Seibert in their study. ${ }^{8}$ Did the school teach bibliographic instructional methods/techniques? In the context of what class(es)? For how long had they been do- 
TABLE 2

SATISFACTION LEVELS OF RESPONDENTS BY TYPE OF TRAINING RECEIVED

\begin{tabular}{llrrrrr}
\hline \hline & Satisfaction Level & 1 & 2 & 3 & 4 & 5 \\
\hline & Library school & 1 & 4 & 2 & 1 & 0 \\
Type of & On-the-job training & 21 & 30 & 14 & 5 & 0 \\
Training & Workshops & 14 & 15 & 5 & 3 & 0 \\
Received: & Observation & 16 & 22 & 10 & 5 & 0 \\
& Trial and error & 20 & 30 & 15 & 4 & 0 \\
& Other & 10 & 9 & 5 & 0 & 0 \\
\hline
\end{tabular}

ing this? Responses are summarized in figure 2 and seem to indicate a rosier picture than Robert Brundin found in 1985.' Techniques or theories of library use instruction are gradually finding a place in curricula. All except one of the forty-eight responding library schools offer at least a few hours of discussion (indicated in figure 2 as "portion"), most in the context of a reference course. Only three schools mentioned teaching bibliographic instruction as part of subject bibliography courses. Fifteen teach an entire course devoted exclusively to library use instruction, although many of those bewailed low enrollment or infrequent offering. In all cases, this course was elective. Five schools had internships or teaching assistantships available to a few students (indicated in figure 2 as "Other"). One school said that it placed less emphasis on library use instruction now than in the heyday of the early 1970 s.

\section{"Since bibliographic instruction has been established long enough to lose the aura of trendiness, it is distress- ing that many library school pro- grams continue to give the field short shrift."}

\section{Library School Curricula: \\ Preparing Librarians to Teach?}

The value of teaching bibliographic instruction skills and the point at which they should be taught has long been argued. ${ }^{10}$ But since even a cursory examination of advertisements for public service (especially academic) librarians shows the desirability of instructional experience, and since bibliographic instruction has been established long enough to lose the aura of trendiness, it is distressing that many library school programs continue to give the field short shrift. Several schools provided enough details of their curricula to indicate that user instruction is passed over in only a few hours of a larger course, usually beginning reference. Several remarked that since students did not realize the importance that bibliographic instruction would have in their careers, elective courses were plagued by lack of enrollment or had lapsed for that reason. No one seemed to connect unenthusiastic student reception with lack of encouragement by counselors or faculty, which I suspect may be an element. One school official commented that bibliographic instruction was more properly taught on the job. On the more positive side, another response suggested that since practicing librarians recognized the value of bibliographic instruction while students didn't, the school was contemplating a series of short-term courses for the experienced librarian.

\section{ATTITUDES}

Science librarians responding to the main survey had positive attitudes about bibliographic instruction and its value to students. Nearly three-quarters checked either 1 or 2 on a five-point scale indicating their preference for bibliographic instruction when compared to their other duties; no one indicated a strong aversion. A slightly smaller percentage of the respondents with an educational background in a scientific field found instruction professionally satisfying: 29 of the $43(67.4 \%)$ rated their satisfaction as 1 or 2 on a fivepoint scale. Likewise, a strong majority ( $n$ $=86$ ) indicated that bibliographic instruc- 


\begin{tabular}{|c|c|c|c|c|}
\hline Nome of scheol & Entire/portion & & Mame of course & Iaught since \\
\hline Brigham Young University & $\begin{array}{l}\text { portions } \\
\text { other }\end{array}$ & 1 & $\begin{array}{l}\text { 1) Reference Theory \& Services } \\
\text { 2) Advanced Reference } \\
\text { 3) } 1 \text { assistantship }\end{array}$ & $\begin{array}{l}1985 \\
1986 \\
1978\end{array}$ \\
\hline Catholic University of Americal & portion & 1 & Information Sources \& Services & 1984 \\
\hline clarion & portions & 1 & "many courses" & $\cdots$ \\
\hline Columbia University & portions & i & $\begin{array}{l}\text { 1) Online Bibliographic Databases } \\
\text { 2) Special Libraries } \\
\text { 3) Science Literature } \\
\text { 4) Academic \& Research Libraries }\end{array}$ & i \\
\hline Dathousie University & entire & 1 & Bibliographic Instruction & 1983 \\
\hline Drexel & entire & 1 & User Education Programs & 1982 \\
\hline Emporia State University & portions & i & $\begin{array}{l}\text { 1) Educational Functions of } \\
\text { Libraries Information Agencies } \\
\text { 2) Applications of Communication } \\
\text { Theory }\end{array}$ & 1 \\
\hline Florida State University & entife & $\begin{array}{l}1 \\
1 \\
1\end{array}$ & $\begin{array}{l}\text { 1) Instructional Services of } \\
\text { Information Professionals } \\
\text { 2) Advanced Reference }\end{array}$ & 1982 \\
\hline Indiana University & portion & I & Information Sources Services & inception \\
\hline Long Island University & portions & I & "academic library courses" & $\cdots$ \\
\hline Louisiana State University & entíre & 1 & Seminar in Bibliographic & 1985 \\
\hline Megill University & portion & 1 & College and University Libraries & $\cdots$ \\
\hline Morthern Illinois University & portions & 1 & "reference and resource courses" & $\cdots$ \\
\hline Pratt Institute & $\begin{array}{l}\text { entire } \\
\text { portion }\end{array}$ & $\begin{array}{l}1 \\
1 \\
1\end{array}$ & $\begin{array}{l}\text { 1) Library Use Instruction } \\
\text { 2) Fundamentals of Information } \\
\text { Hendling }\end{array}$ & $\begin{array}{l}1982,1987 \\
1950 \text { 's }\end{array}$ \\
\hline Queens College & portíons & I & $\begin{array}{l}\text { 1) "basic reference" } \\
\text { 2) "social science reference" }\end{array}$ & $\cdots$ \\
\hline Rosary College & portions & i & $\begin{array}{l}\text { 1) "introductory reference and } \\
\text { biblfography" } \\
\text { 2) "ocadenic libraries" }\end{array}$ & 21970 \\
\hline Rutgers University & $\begin{array}{l}\text { entire } \\
\text { portion }\end{array}$ & i & $\begin{array}{l}\text { 1) Professional Development } \\
\text { 2) "academic libraries" }\end{array}$ & $\cdots$ \\
\hline
\end{tabular}

FIGURE 2

Responses to Bibliographic Instruction in Library Schools Questionnaire 


\begin{tabular}{|c|c|c|c|c|}
\hline St. John's University & portions & $\begin{array}{ll}\text { 1 } & \text { 1) } \\
1 & \text { 2) } \\
1 & 31 \\
1 & 4) \\
1 & 51 \\
1 & 61\end{array}$ & $\begin{array}{l}\text { "introductory" } \\
\text { "science biblfography" } \\
\text { "social science bibliography" } \\
\text { "humanities bibliography } \\
\text { "advanced reference" } \\
\text { "Internship" }\end{array}$ & late 1970 's \\
\hline San Jose State University & entíre & Libi & $\begin{array}{l}\text { brary } 2 \text { Information Research } \\
\text { Instruction }\end{array}$ & "rarely" \\
\hline Simmons College & portions & 1) & $\begin{array}{l}\text { "basic reference" } \\
\text { Bibllographic Instruction \& } \\
\text { Methods }\end{array}$ & "years" \\
\hline s. Connecticut State Univ. & $\begin{array}{l}\text { entire } \\
\text { portion }\end{array}$ & 1) & $\begin{array}{l}\text { Library Instruction } \\
\text { Advanced Reference }\end{array}$ & $\cdots$ \\
\hline state U. of Wew York, Buffalo I & entíre & Bib & blfographic Instruction & 1987 \\
\hline Texas Women's University & portions & 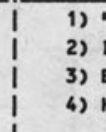 & $\begin{array}{l}\text { "academic Libraries" } \\
\text { Information Sources \& Services } \\
\text { Educating for Librarianship } \\
\text { Health Science Libraries }\end{array}$ & 19827 \\
\hline University of Alabama & & bibl & $\begin{array}{l}\text { bllographic instruction } \\
\text { assistantships }\end{array}$ & 1976 \\
\hline University of Alberta & portions & 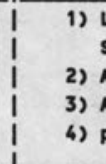 & $\begin{array}{l}\text { Library Material Information } \\
\text { Services } \\
\text { Advanced Information Services } \\
\text { Academic Libraries } \\
\text { practicum }\end{array}$ & Q1978 \\
\hline University of Arizona & portions & $\begin{array}{l}\text { 1) } \\
\text { 2) } \\
\text { 3) }\end{array}$ & $\begin{array}{l}\text { Reference } \\
\text { Public Libraries } \\
\text { Academic Libraries }\end{array}$ & 1981 \\
\hline University of British Columbial & portion & "adv & dvanced reference" & $1975 ?$ \\
\hline U. of Callfornia, Berkeley & portions & $\begin{array}{l}\text { 1) } \\
\text { 2) } \\
\text { 3) } \\
\text { 5) } 1\end{array}$ & $\begin{array}{l}\text { Introduction to Information } \\
\text { Advanced Reference } \\
\text { Health Sciences } \\
\text { Law } \\
\text { Internship }\end{array}$ & $\cdots$ \\
\hline U. of California, Los Angeles & $\begin{array}{l}\text { portions } \\
\text { entire } \\
\text { other }\end{array}$ & $\begin{array}{lll}1 & 11 & 1 \\
1 & 23 & 1 \\
1 & 37 & 1 \\
1 & 43\end{array}$ & $\begin{array}{l}\text { Information Resources Services } \\
\text { Internship } \\
\text { Training supervision of } \\
\text { Teaching Assistants } \\
\text { teaching assistantships }\end{array}$ & 1976 \\
\hline
\end{tabular}

\section{FIGURE 2}

Continued 


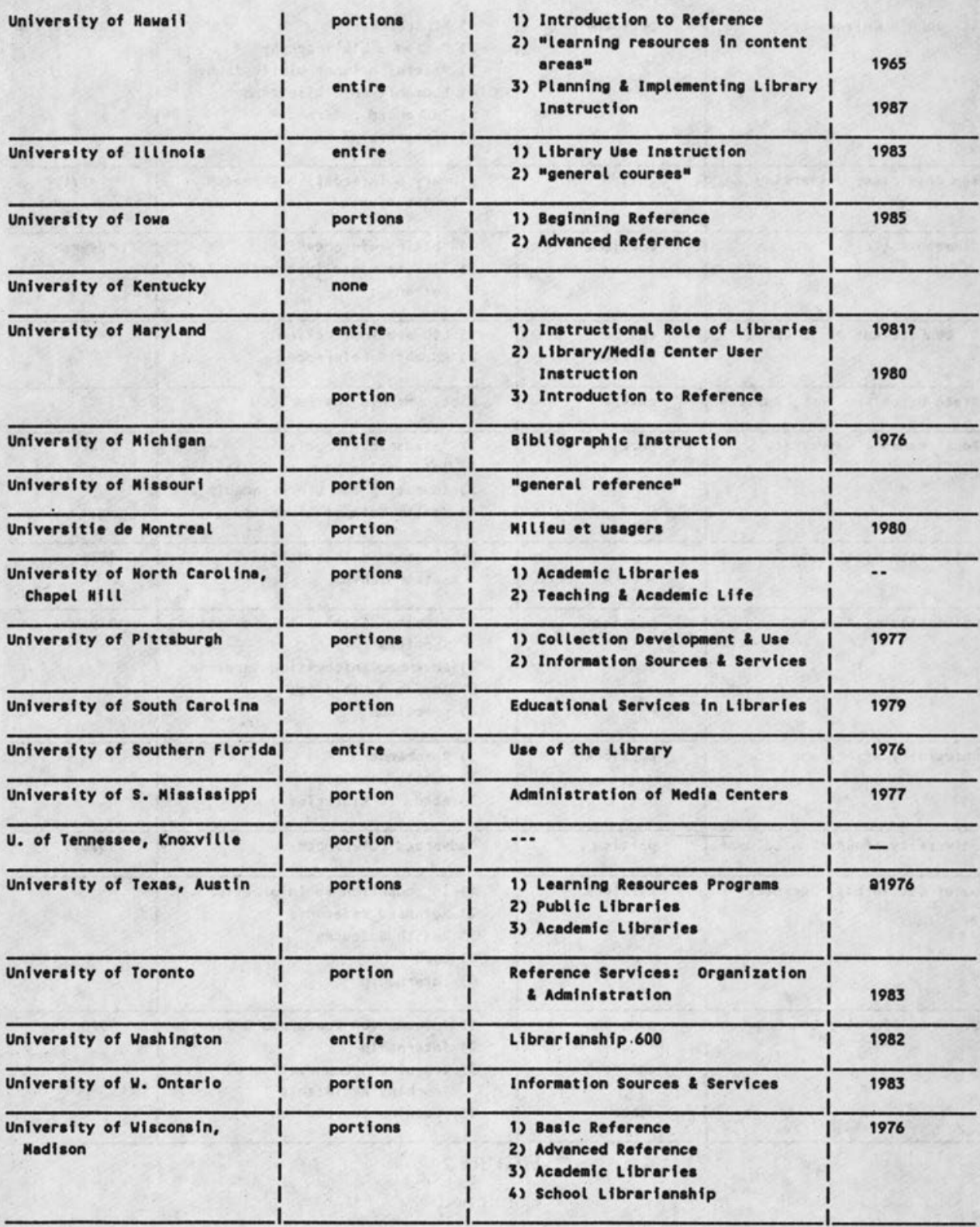

FIGURE 2

Continued 
tion was valuable to students at a 1 or 2 level on a five-point scale. Two-thirds [ $n$ $=66$ ] responded 1 or 2 to both five-point scales (work satisfaction attitudes; perceptions of the value of bibliographic instruction to students).

Not surprisingly, the large majority of respondents was engaged in fairly traditional bibliographic instruction, the "onehour" stand, ninety-five giving one-time lectures requested by teaching faculty, and seventy-four engaged in one-time library-initiated lectures. A sizable minority [ $n=30]$ of librarians taught quarter- or semester-length courses, while fifteen gave shorter courses. Regardless of the type of instruction with which they were involved, tables 3 and 4 show that librarians believed instruction to be valuable to students; and most enjoyed their instructional duties.

\section{CONCLUSIONS}

Answers to the questions that led to my survey of science librarians can be summarized:

1. Most respondents had not received systematic training from their institutions. Karen Stabler's study indicates that this is neither a new condition nor limited to California. ${ }^{11}$

2. Instructional librarians pursue various means of improving their skills.

3. The question of librarians giving bibliographic instruction only in areas con- gruent with their own subject backgrounds was split: about half of the librarians surveyed gave library use instruction only in areas in which they themselves had some education; about half were not limited in this manner.

4. Enjoyment level was high. The majority of librarians giving bibliographic instruction in each discipline rated their enjoyment at the 1 or 2 level.

5. Library schools are slowly increasing their offerings in bibliographic instruction, but the situation is not ideal.

Respondents to this survey were an experienced and highly motivated group with very positive attitudes about the need for and the value of library use instruction. A majority of both very experienced and less experienced librarians took advantage of diverse training methods to hone their instructional skills. This interest in professional development is especially laudable in light of the cursory treatment still given bibliographic instruction by library schools. For the foreseeable future, it must be recognized that newly minted librarians are unlikely to have been taught bibliographic instruction techniques in school. Because a library cannot expect that new graduates will meet its instructional standards, each library must create its own program or find other means of developing new professionals.

TABLE 3

SATISFACTION LEVELS OF RESPONDENTS BY TYPE OF INSTRUCTION

\begin{tabular}{llrrrrr}
\hline \hline & Satisfaction Level & 1 & 2 & 3 & 4 & 5 \\
\hline & Library initiated & 22 & 33 & 15 & 3 & 0 \\
Type of & Professor requested & 30 & 39 & 19 & 6 & 0 \\
Instructional & Full course & 11 & 11 & 4 & 4 & 0 \\
Program: & Brief & 4 & 10 & 1 & 0 & 0 \\
& Other & 9 & 7 & 4 & 0 & 0 \\
\hline
\end{tabular}

TABLE 4

OPINION LEVELS OF RESPONDENTS ABOUT VALUE OF INSTRUCTION TO STUDENTS BY TYPE OF INSTRUCTION

\begin{tabular}{llccccc}
\hline \hline & Opinion Level & 1 & 2 & 3 & 4 & 5 \\
\hline & Library initiated & 43 & 20 & 6 & 3 & 0 \\
Type of & Professor requested & 56 & 25 & 8 & 4 & 0 \\
Instructional & Full course & 22 & 5 & 1 & 2 & 0 \\
Program: & Brief & 8 & 0 & 1 & 0 & 0 \\
& Other & 14 & 6 & 0 & 1 & 0 \\
\hline
\end{tabular}




\section{REFERENCES AND NOTES}

1. Wendy Culotta, "Getting Involved in Science Bibliographic Instruction: The Role of the General Reference Librarian," paper delivered at a joint meeting of California Clearinghouse for Library Instruction and Science and Engineering Academic Librarians, Los Angeles, January 21, 1984.

2. Barbara J. Smith, "Background Characteristics and Education Needs of a Group of Instruction Librarians in Pennsylvania," College \& Research Libraries 43:199-207 (1982).

3. Barbara Magnuson, ed., SEAL Directory of California Academic and Research Librarians in Science and Engineering. (Northridge, Calif.: Science \& Engineering Academic Librarians, 1985).

4. Karen Y. Stabler, "Introductory Training of Academic Reference Librarians: A Survey," RQ, 26:363-69 (1987).

5. J. R. Kennedy, "Question: A Separate Course in Bibliographic Instruction or Course-Related Library Instruction?"' in S. H. Lee, ed., Library Orientation: Papers Presented at the First Annual Conference on Library Orientation Held at Eastern Michigan University, May 7, 1971 (Ann Arbor: Pierian Press, 1972).

6. Sue Galloway, "Nobody Is Teaching the Teachers," Booklegger 3:29-31 (1976).

7. Ibid; Marilyn Lutzker, "On-the-job Training for Instruction Librarians," Reference Services Review 10:63-64 (1982); Lisa Howarth and Donald Kenney, "Education for Bibliographic Instruction: A Syllabi Project," College \& Research Libraries News 10:379-80 (1983).

8. Maureen Pastine and Karen Seibert, "Update on the Status of Bibliographic Instruction in Library School Programs," Journal of Education for Librarianship 21:169-71 (1980).

9. Robert Brundin, "Education for Instructional Librarians: Development and Overview, " Journal of Education for Library and Information Science 25:177-89 (1985).

10. Carolyn Kirkendall, ed., "Library Instruction, a Column of Opinion: Should Library Schools Teach Library Instruction?" Journal of Academic Librarianship 8:34-35 (1982).

11. Karen Y. Stabler, "Introductory Training of Academic Reference Librarians: A Survey," RQ, 26-363:69 (1987).

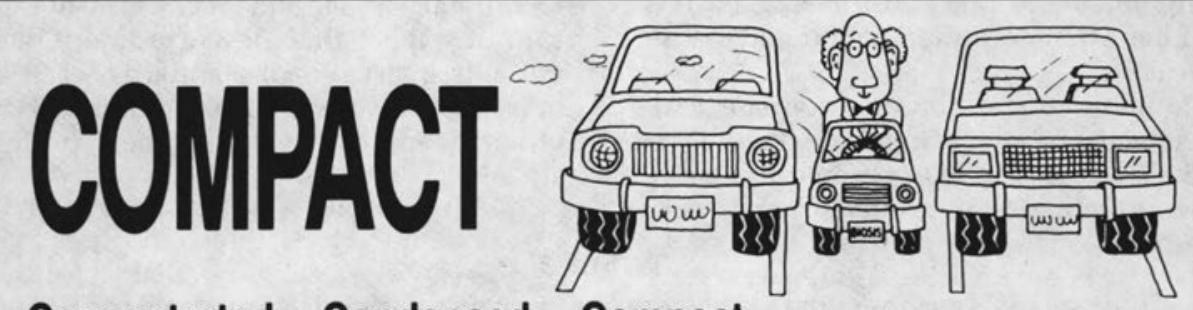

\section{Concentrated... Condensed... Compact...}

No matter how you say it, smaller is better. People want more information in a smaller package.

And that's what you get with Biological Abstracts ${ }^{\star}$ in microform as your life sciences reference tool. Delivering the scope of coverage you've come to expect from BIOSIS ${ }^{*}$, BA in microform provides you with rapid access and saves a lot of shelf space. In fact, you can store 18 years' worth of $\mathbf{B A}$ in microform in the same amount of space taken up by just one year of the printed publication!

See for yourself. Contact BIOSIS Markèting Section, 2100 Arch Street, Philadelphia, PA 19103-1399 USA; Tel. (215) 587-4800 (worldwide); toll free 1-800-523-4806 (USA except PA). Telex 831739; Fax (215) 587-2016.

\section{BIOLOGICAL ABSTRACTS IN MICROFORM}

BIOSIS is a not-for-profit organization serving the biological community since 1926.

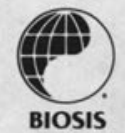

